medRxiv preprint doi: https://doi.org/10.1101/2021.05.11.21257023; this version posted May 12, 2021. The copyright holder for this preprint (which was not certified by peer review) is the author/funder, who has granted medRxiv a license to display the preprint in perpetuity. All rights reserved. No reuse allowed without permission.

\title{
An AI-based quantitative home-use framework for assessing fertility and identifying novel hormone trends by recording urine hormones
}

\section{Siddharth Pattnaik, Dipankar Das, Varun Akur Venkatesan}

\section{Summary}

\section{Background}

Fertility testing using urinary hormones has been used to improve the likelihood of pregnancy effectively. To provide fertility scores, the existing home-use systems measure one or two hormones. However, the hormone profiles vary depending on cycle duration, fertility-related disorders, drugs and other treatments. Here we introduce Inito, a mobile-phone connected reader that is scalable to multiple hormone tests. In this report, we assess the accuracy of the quantitative home-based fertility monitor, Inito Fertility Monitor (IFM), and suggest using IFM as a device to monitor and analyse female hormone patterns. We further show that Inito can be used as a tool to decipher novel hormone patterns in a more profound way than the existing knowledge in the field.

\section{Methods}

There were two aspects to our analysis: i. Evaluation of Inito Fertility Monitor efficiency characteristics for urinary Estrone-3-glucuronide (E3G), Pregnanediol glucuronide (PdG) and Luteinizing hormone (LH) assessment, and ii. A retrospective study of patients' hormone profiles using IFM. For the performance assessment, the recovery percentage of the three hormones from IFM was evaluated using standard spiked solutions, the reproducibility of re-prediction and the correlation between re-predicted values from IFM and ELISA. The first urine sample of the day was collected from 100 women who volunteered for the study and IFM was provided to 52 more women to use it at home to track their fertile days.

\section{Finding}

We observed that with all three hormones, IFM had an accurate recovery percentage and had a CV of less than 10 percent for separate test strips through tests of the same dosage making it a reliable tool to monitor hormone patterns of patients. Furthermore, in predicting the concentration of E3G, PdG and LH in urine samples, we show that IFM has a high correlation with ELISA. We show that certain hormone trends associated with urinary E3G, PdG and LH could be accurately captured using IFM. In addition, we report a novel criterion for earlier confirmation of ovulation compared to existing criteria. Finally, we present a novel hormone pattern associated with most of the menstrual cycles by examining hormone profiles from the volunteers recruited for the clinical trial. 
medRxiv preprint doi: https://doi.org/10.1101/2021.05.11.21257023; this version posted May 12, 2021. The copyright holder for this preprint (which was not certified by peer review) is the author/funder, who has granted medRxiv a license to display the preprint in perpetuity.

\section{Interpretation}

The Inito Fertility Monitor is an effective tool for calculating the urinary concentrations of E3G, PdG and LH and can also be used to provide accurate fertility scores and confirm ovulation. In addition, the sensitivity of IFM facilitates the monitoring of menstrual cycle-related hormone patterns, therefore also making it a great tool for physicians to track the hormones of their patients.

\section{Introduction}

For couples seeking to conceive, the timing of intercourse is a critical question. Almost 45-50 percent of women do not know their fertile window ${ }^{1,2}$. Calendar based methods cannot accurately predict the fertile window. During the fertile window, having intercourse increases the likelihood of becoming pregnant ${ }^{3}$. Based on different factors, such as age, diet, genetic predisposition and any infertility disorder, the fertile window may vary.

The pituitary hormones, FSH and LH, and steroid hormones, Estrogen and Progesterone, regulate follicle formation, egg release and uterine preparation for implantation. The predictable behavior of these hormones in a regular menstrual cycle can be exploited to forecast fertile days. Lateral flow assay based luteinizing hormone tests at home have widely been used to estimate fertile days. These tests, however, provide a window of 1-2 fertile days(s) near the ovulation day. Previous studies have concluded that the fertile window usually lasts for 6 days and involves the ovulation date ${ }^{4-6}$. Measuring estrone-3-glucuronide (E3G) along with LH can potentially boost the fertility window from 2 days to 6 days. Predicting the fertility status by evaluating the levels of LH and oestrogen is also highly correlated with transvaginal ultrasound ovulation prediction ${ }^{7}$. Fertile window estimation, however, is not a guarantee of ovulation. In fact, about $37-42 \%$ of natural cycles are anovulatory $^{8}$. This may lead to frustration for couples trying to conceive. Therefore, the confirmation of ovulation is sought after by both clinicians and patients and an additional measurement of Pregnanediol-3-glucuronide (PdG) can be used to confirm ovulation ${ }^{9,10}$.

Women use many home-use tests to predict fertile days in the menstrual cycle. Canonical over-the-counter ovulation test kits only assess urinary LH and thus skip a series of fertile days. Other home-use devices available on the market forecast fertile days by tracking LH and E3G. Getting a full fertile window can increase the chances of conception by around $89 \%$ (3). These home-use techniques, however, have low sensitivity and a lower detection range. Most of these tests are either visual or provide a binary digital result (positive or negative). However, the hormone patterns are more complex and need quantification. Furthermore, physicians and users are keen on visualizing their hormone trends. Therefore, there's a need for a more sensitive, quantitative 
medRxiv preprint doi: https://doi.org/10.1101/2021.05.11.21257023; this version posted May 12, 2021. The copyright holder for this preprint (which was not certified by peer review) is the author/funder, who has granted medRxiv a license to display the preprint in perpetuity. All rights reserved. No reuse allowed without permission.

home-based test to account for person-to-person and cycle-to-cycle variability while predicting fertile days in women.

We introduce the Inito Fertility Monitor (IFM) (Fig.1b and c), a mobile mounted, app-connected home based device that predicts the fertile days and also confirms ovulation by measuring E3G, LH and PdG simultaneously in urine. The test strip for IFM contains two lateral flow assays: one assay is multiplexed to measure $\mathrm{E} 3 \mathrm{G}$ and $\mathrm{PdG}$ in a competitive ELISA format and the other assay measures LH in a sandwich ELISA format. IFM captures the image of the test strip using the Inito mobile application and processes the image to yield the optical density (OD) which corresponds to the concentration of the metabolite. IFM uses a multi-scale algorithm to detect the device and eliminate the variations in resolution and aspect ratio due to smartphone variability ${ }^{11}$.

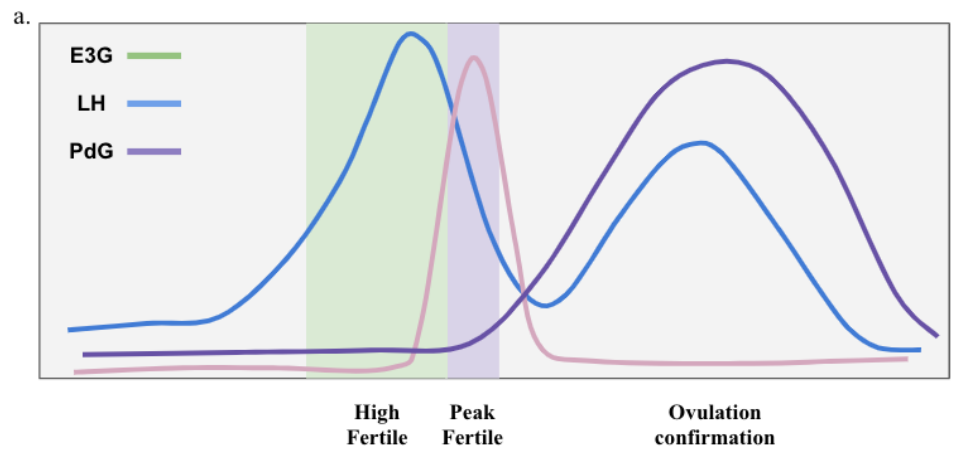

b.

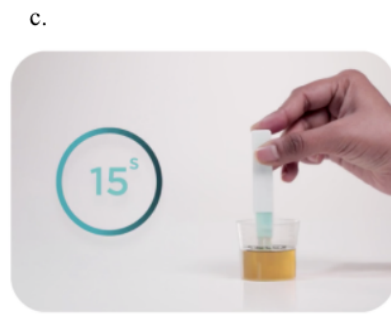

Dip test strip in urine

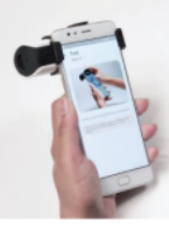

Attach Inito Fertility Monitor to your phone

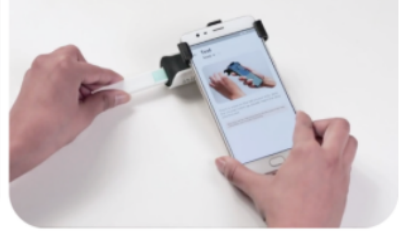

Insert test strip into the device

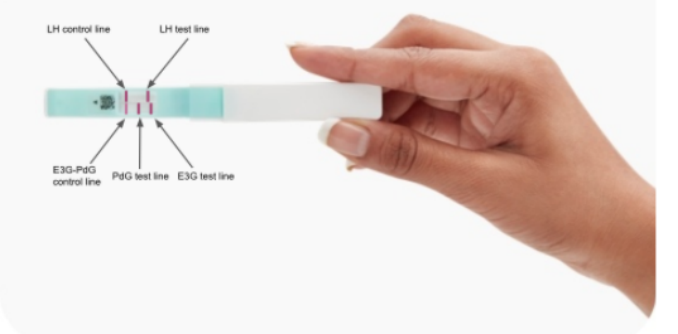

Figure 1. Behaviour of urinary hormones E3G, PdG and LH in a normal menstrual cycle and the prediction of high fertility, peak fertility and ovulation confirmation based on hormone levels (a), location of testing regions in the Inito fertility test strips (b) and schematic of usage of the Inito Fertility Monitor at home (c).

Here we show that IFM is an effective urinary hormone monitor and has a laboratory-based ELISA-equivalent output that makes it ideal for predicting fertile days and confirming ovulation at home. Using IFM, we could reproduce hormone trends that have been previously reported for example, premature E3G surge and multiple LH surge in menstrual cycles. In addition, by observing trends in the urinary PdG rise after the LH peak, we propose a novel criteria to confirm ovulation earlier in women. Also, we present a previously unreported incidence of PdG rise before the LH surge. In conclusion, we suggest that IFM can be used by women at home to monitor their 
medRxiv preprint doi: https://doi.org/10.1101/2021.05.11.21257023; this version posted May 12, 2021. The copyright holder for this preprint (which was not certified by peer review) is the author/funder, who has granted medRxiv a license to display the preprint in perpetuity. All rights reserved. No reuse allowed without permission.

fertile days and by clinicians to monitor patients' hormone profiles and to tailor intervention in the future as well.

\section{Materials and methods}

\section{Testing with IFM and repredicition from calibration curve}

Calibration curve for each batch of Inito Fertility test strips was generated using standard solutions prepared in spiked urine. The ODs obtained from standard solutions were plotted against concentration and this plot was used to re-predict concentrations in all further experiments. For testing, the test strips were dipping in the urine samples for 15 seconds. The strips were then inserted into the Inito Fertility Monitor attached to mobile and values of E3G, PdG and LH were obtained along with the fertility ratings for each day. In the Inito Fertility test strip, E3G and PdG are measured in a competitive ELISA assay format where the intensity of respective test lines decreases with increasing concentration and LH is measured in a sandwich ELISA format where the intensity of the test line increases with increasing concentration.

\section{Sample preparation for characterization of Inito Fertility Monitor}

Samples used for precision studies, linearity of re-prediction of concentration and cross-reactivity studies were prepared by spiking male urine samples with target concentrations of the metabolites. The male urine samples were tested with ELISA to confirm negligible concentrations of the respective metabolites. Purified metabolites for all studies were obtained from Sigma-Aldrich chemicals as described in supplementary table 1 .

\section{Testing with ELISA kits}

The same user samples were also used in an ELISA to measure the exact concentration. E3G and PdG were measured using the Arbor Estrone-3-Glucuronide EIA kit (K036-H5) and the Arbor Pregnanediol-3-Glucuronide EIA kit (K037-H5) ELISA kits. Urinary LH was measured using the DRG LH (urine) ELISA kit (EIA-1290). For all runs, solutions of fixed concentration (provided along with the respective kits) were used to generate the standard curve and the concentration of metabolites in urine samples were calculated from the standard curve generated. All samples were measured in triplicates and the average value was considered for comparison.

\section{Study participants}

Two groups of women were recruited for the study. The first group consisted of women from whom the first urine sample of the day was collected over one menstrual cycle. The second groups consisted of women who had expressed previous interest over the internet to try the Inito Fertility 
medRxiv preprint doi: https://doi.org/10.1101/2021.05.11.21257023; this version posted May 12, 2021. The copyright holder for this preprint (which was not certified by peer review) is the author/funder, who has granted medRxiv a license to display the preprint in perpetuity. All rights reserved. No reuse allowed without permission.

Monitor. Women in the second group were provided the IFM and the Inito Fertility Test strips to be tested at home. The study protocol was approved by the appropriate institutional review boards (ISRCTN15534557). Informed consent forms were obtained from all volunteers. Women aged between 21-45 years of age were recruited for the study. Women were excluded if:

a. They were using hormonal contraceptives, including oral, emergency oral, implants, patches, transdermal injections, vaginal ring and progesterone intrauterine systems (IUS)

b. Were on infertility medications or hormone replacement therapy containing hCG or LH

c. Were consuming clomiphene citrate or other ovulation induction drugs

d. Have recently been pregnant, miscarried or breastfeeding

Reasons for data exclusion were irregularities in testing leading to insufficient data points for any conclusion and failure to meet the selection criteria. The characteristics of those who were considered for the study are summarized in Table 1.

\section{Study design}

Urine samples collected from women in the first group were frozen, transported to the testing site and tested with the IFM on the same day. Freeze-thaw has been previously shown to have no effect on the concentration of urinary hormones ${ }^{12,13}$. For the second group, IFM and Inito Fertility test strips were sent to participants to perform the test at home. Standard instructions for use were provided with the IFM box and the test strips. All participants had the option to contact the manufacturer's helpline number for any additional information concerning the IFM. Women began using the IFM at the start of the menstrual cycle after admission into the study. Participants were instructed to take tests on specific cycle days when instructed by the application. Hormone data from all participants was collected via the Inito application. Although women were recruited for one cycle each, participants were excluded if they did not take tests on the required days The study design is summarized in Figure 2. 
medRxiv preprint doi: https://doi.org/10.1101/2021.05.11.21257023; this version posted May 12, 2021. The copyright holder for this preprint (which was not certified by peer review) is the author/funder, who has granted medRxiv a license to display the preprint in perpetuity. All rights reserved. No reuse allowed without permission.

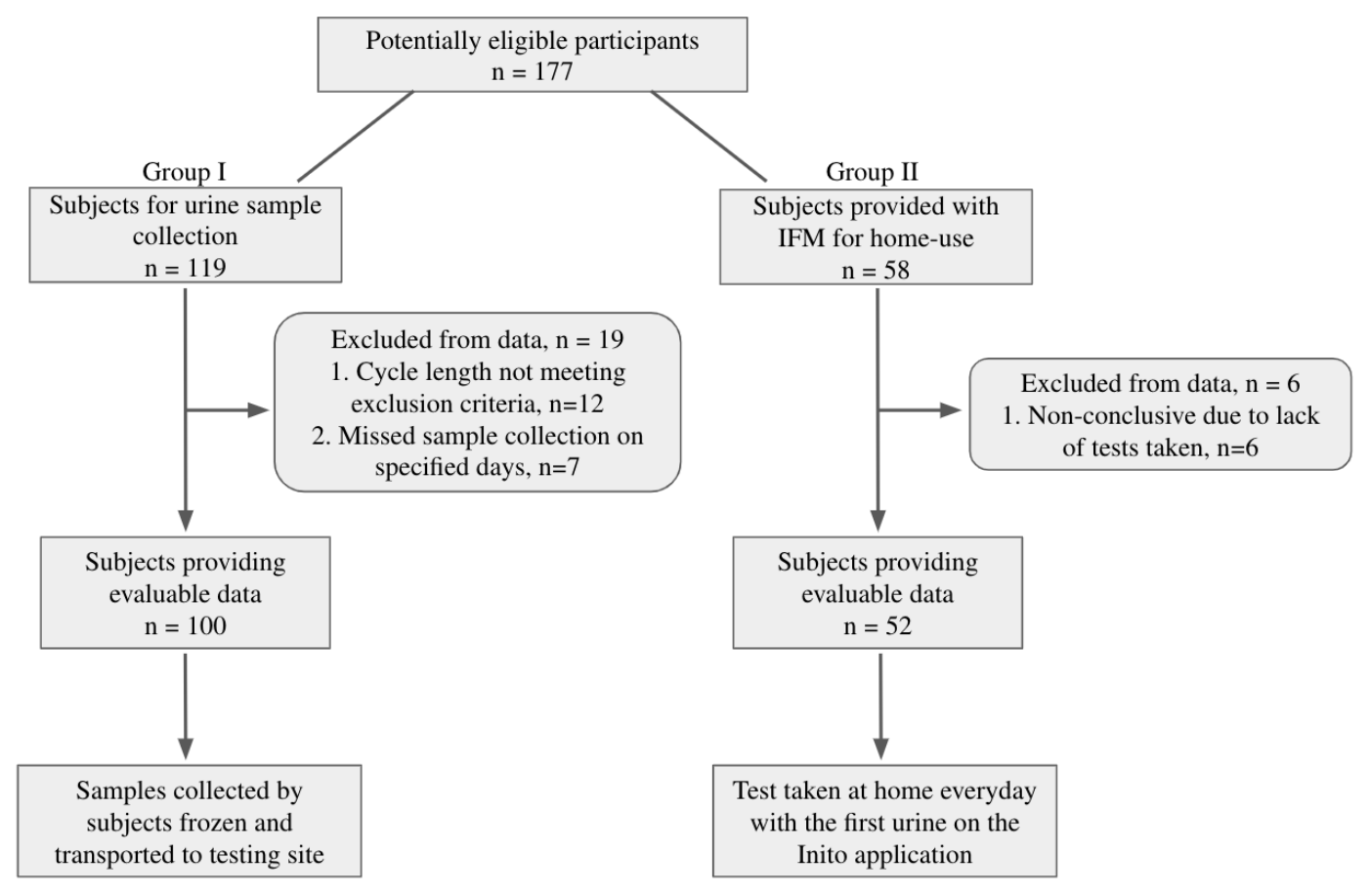

Figure 2. Flow of participants through the study

\section{Results}

Inito fertility monitor accurately predicts the concentration of urine metabolites and is specific to the metabolites of interest

Accuracy of the Inito Fertility test strips was assessed by re-predicting the concentrations of E3G, PdG and LH in standard solutions prepared in male urine not containing any of the metabolites. Six spiked solutions containing all the three metabolites were prepared from respective stock solutions as per Supplementary Table 2. Each solution was tested with five different Inito fertility test strips and the recovery percentage was calculated. We found that the average recovery percentage across five tests was $100.16 \%$ for E3G, 104.63\% for PdG and 104.74\% for LH. The observed concentration obtained from IFM was also highly correlated to the expected concentration in the spiked male urine (Fig.3a-c) implying a high accuracy in predicting the concentrations.

Since Inito Fertility test strips are manufactured in a batch wise fashion, we wanted to ensure that the accuracy is maintained across lots. Therefore, ten strips from different lots were tested with four different concentrations of E3G, PdG and LH and the coefficient of variation (CV) was calculated. All three assays were found to have a CV of less than 10\% across different lots (Supplementary Table 3), indicating that the recovery percentage does not vary significantly from test strip to test strip. Therefore, IFM is an accurate device to measure urinary hormones and is consistent from test to test. 
medRxiv preprint doi: https://doi.org/10.1101/2021.05.11.21257023; this version posted May 12, 2021. The copyright holder for this preprint (which was not certified by peer review) is the author/funder, who has granted medRxiv a license to display the preprint in perpetuity. All rights reserved. No reuse allowed without permission.

Next, we wanted to analyse the specificity of Inito fertility test strips towards the metabolites of interest. We identified the components of human urine that could potentially interfere with the test and spiked negative male urine with these compounds. The concentration of each metabolite was selected to encompass normal and pathological conditions. We tested four strips from different batches with the spiked male urine and found that the test strips did not cross-react with any urine metabolite at even the highest possible physiological condition (Supplementary Table 4). This suggests that the Inito fertility test strips are specific to the metabolites of interest only.

\section{Urinary hormone concentrations estimated by IFM and ELISA are strongly correlated}

Enzyme linked-immunosorbent assay (ELISA) is a standard laboratory procedure for measuring concentrations of chemical compounds accurately. Therefore, we wanted to compare the efficacy of estimation by Inito with respect to ELISA. For this, we chose urine samples from three random user cycles of the 100 volunteer cycles. This accounted for a total of 80 samples that were tested with both Inito and ELISA and the correlation was calculated. We found that results obtained from ELISA and Inito are highly similar $\left(r^{2}=0.96\right.$ for E3G, $r^{2}=0.99$ for $\mathrm{PdG}$, and $\mathrm{r}^{2}=0.99$ for $\left.\mathrm{LH}\right)$ and are linearly correlated (Fig.3d-f) implying that measurement by Inito is almost as accurate as measurement by a standard laboratory technique.

a.

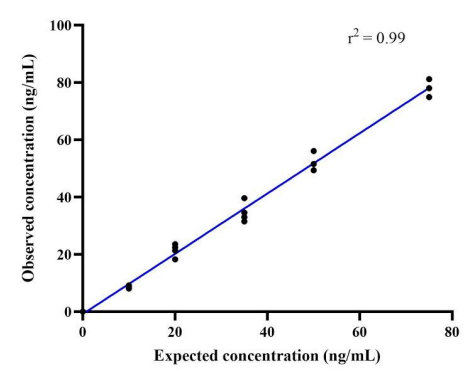

d.

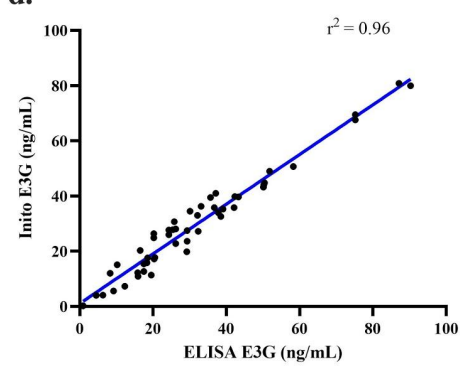

b.

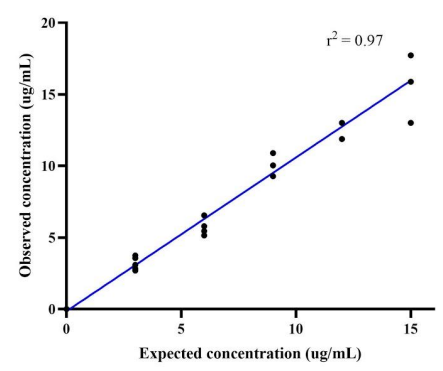

e.

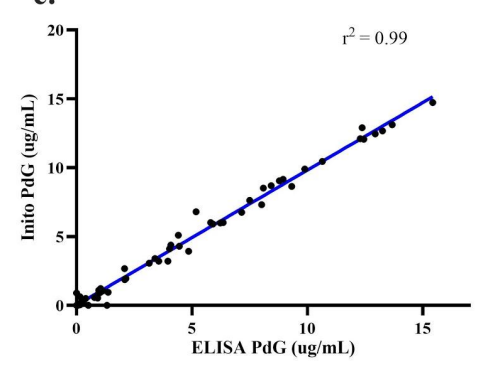

c.

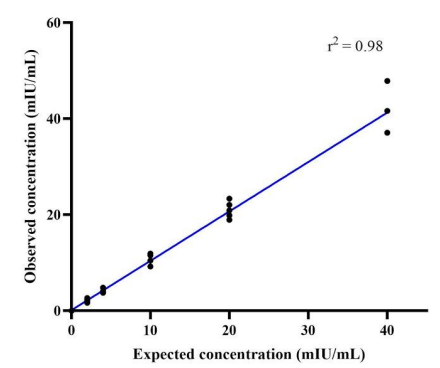

f.

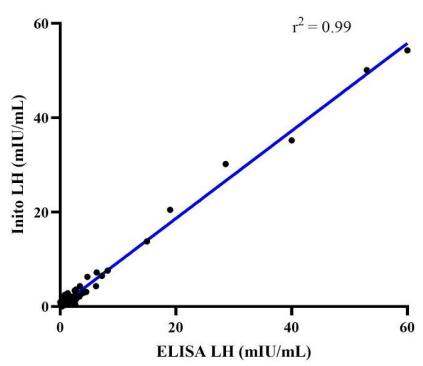

Figure 3. Correlation between observed concentration as obtained from IFM and expected concentrations of E3G (a), PdG (b) and LH (c). Linear regression (blue) along with the 95\% CI (dotted black line) for the comparison between re-predicted hormone values from urine samples obtained using IFM and ELISA: E3G (d), PdG (e) and LH (f). 
medRxiv preprint doi: https://doi.org/10.1101/2021.05.11.21257023; this version posted May 12, 2021. The copyright holder for this preprint (which was not certified by peer review) is the author/funder, who has granted medRxiv a license to display the preprint in perpetuity.

\section{Incidence of premature E3G surge and multi-phasic LH surge maybe higher in women than expected}

Our study design allowed us to monitor urinary E3G, LH and PdG on all days of the follicular phase and the luteal phase including the day of ovulation. Therefore, we decided to observe the occurrence of aberrant E3G and LH patterns in the volunteer menstrual cycles. Specifically, we investigated the prevalence of premature E3G surge and multi-phasic LH surge (multiple LH peaks). We observed that among the cycles which displayed LH rise and ovulation (confirmed using urinary PdG), 39 cycles recorded multiple surges of $\mathrm{LH}$ before the actual peak that caused ovulation and 16 cycles recorded a single dominant LH surge. 39 cycles were anovulatory and had no LH surge. However, 6 cycles were anovulatory despite a single surge of LH, a phenomenon previously described as luteinized anovulation. While the occurrence of multi-phasic LH is coincident with previous studies ${ }^{14,15}$, the percentage of cycles with a single LH surge leading to ovulation may actually be lower than what had been previously assumed. With respect to E3G, we observed that 20 cycles showed a significantly high E3G in the early part of the cycle and before the expected E3G surge (right before LH surge) the occurrence of which is coincident, albeit slightly higher than previously reported studies ${ }^{15}$.

\section{Monitoring continuous rise of urinary PdG after LH surge provides early confirmation of ovulation}

Serum progesterone (P4) concentration is widely considered as a confirmatory marker for ovulation. Typically, a mid-luteal phase value of $>3 \mathrm{ng} / \mathrm{mL}$ has been used to confirm ovulation. Recently, it has been shown that mid-luteal phase measurement of urinary PdG (a threshold value of $>5 \mathrm{ug} / \mathrm{mL}$ ) has a good correlation with serum P4 behaviour and can also be used to confirm ovulation $^{16,17}$. However, both these methods require the users/patients to wait for almost 7 days after the LH surge.

For our analysis, to classify a menstrual cycle as ovulatory or anovulatory, we selected the same urinary PdG threshold values as previously discussed and this was regarded as the actual positive or negative value for further evaluation of the novel criteria. The baseline urinary PdG was determined before the LH surge as the average of the PdG levels and compared with the PdG levels 2-3 days after the LH surge. We found that the distribution of fold change in ovulatory cycles was substantially different from the fold change observed in the anovulatory cycles during the first three days after the LH peak (Fig.4a and b). From this observation, we inquired if measuring a particular fold rise within 3 days after the LH peak could be used as a criteria to predict ovulation earlier. We decided to judge this criteria by performing an ROC analysis. We found that a fold change of $2.75 \mathrm{x}$ within 3 days could accurately distinguish ovulatory from anovulatory cycles. The criteria had a specificity and sensitivity of $100 \%$ in detecting ovulation and was significant in differentiating the ovulatory from anovulatory cycles ( $<<0.0001$, AUC:0.981, Fig.4c and Table $2 a)$. In addition, we 
medRxiv preprint doi: https://doi.org/10.1101/2021.05.11.21257023; this version posted May 12, 2021. The copyright holder for this preprint (which was not certified by peer review) is the author/funder, who has granted medRxiv a license to display the preprint in perpetuity. All rights reserved. No reuse allowed without permission.

applied this criterion to the set of users who used the IFM at home to predict ovulation. We found that the new criteria could differentiate the 18 ovulatory cycles from the 4 anovulatory cycles with a $100 \%$ precision (Table $2 \mathrm{~b}$ ). Our findings show that constant urinary PdG monitoring can provide earlier ovulation confirmation instead of a single PdG/P4 measurement in the mid-luteal phase.

\section{Surge in luteinizing hormone is preceded by a distinct rise in the urinary PdG}

A surge in estradiol levels prior to the LH surge is observed in canonical menstrual cycles.

Progesterone, however, is thought to be the baseline during the follicular phase (Fig.1a). Our study design allowed us to monitor urinary PdG prior to LH surge as well. Furthermore, the sensitivity of the Inito Fertility test strips allowed the smallest changes in the urinary PdG to be visualised. We observed that urinary PdG increased in Group I prior to the LH surge by an average of 3.16+/-0.7 fold in 52/55 cycles from the baseline stage (in cycles where there was a prominent LH surge). Just 2 cycles illustrated this phenomenon in the 6 anovulatory cycles of Group I, where there was an LH surge. In Group II, we found the frequency of this phenomenon in 43/52 cycles by re-evaluating this observation. Although we remain unsure of the source of this urinary PdG, the phenomenon appears to be highly conserved during menstrual cycles.
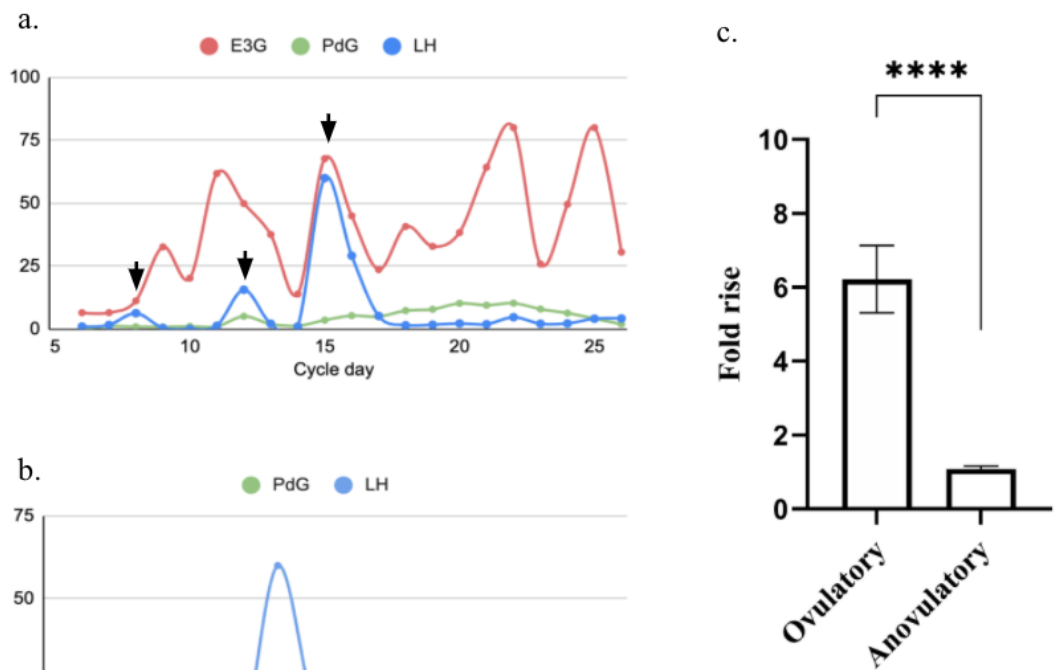

d.
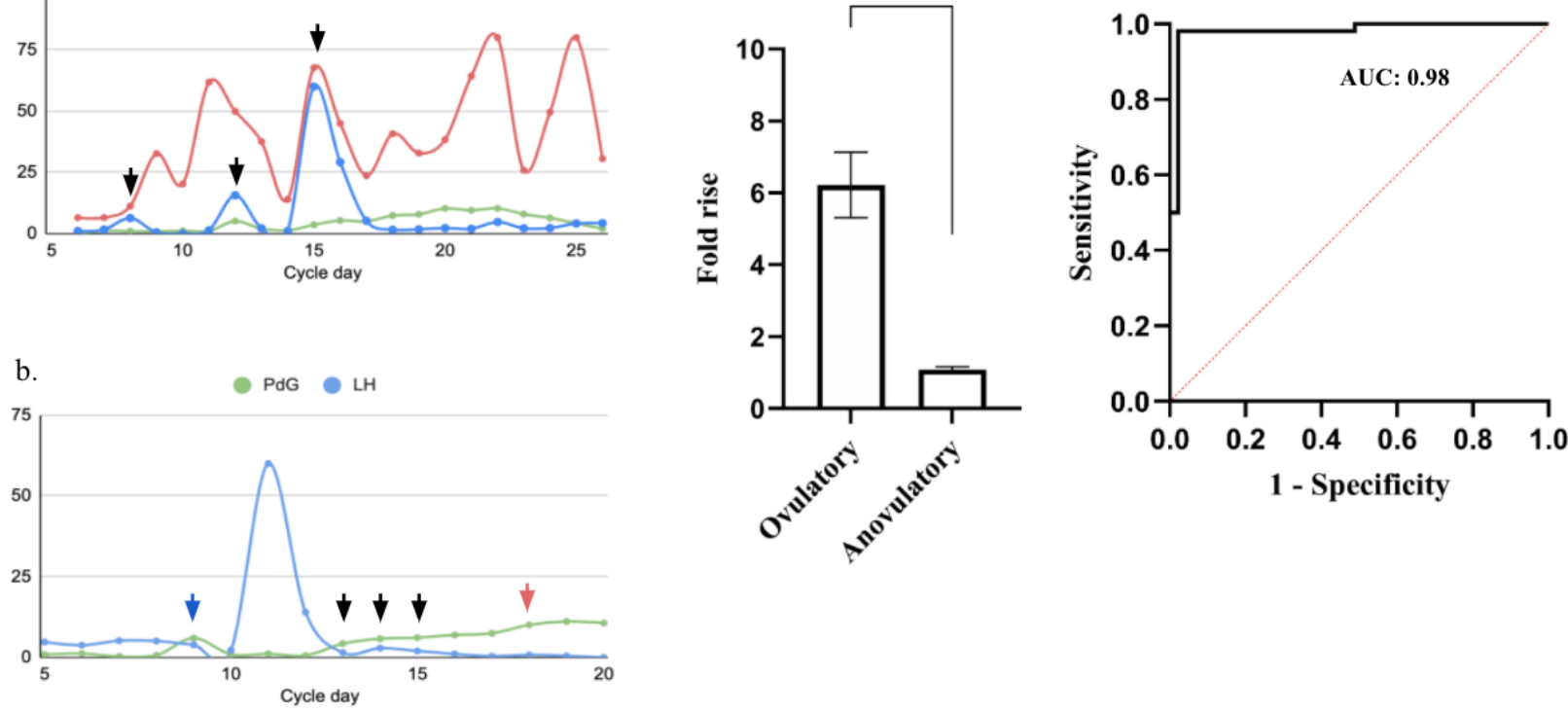

Figure 4. a. Representative hormone chart for multi-phasic LH surges with each event of LH surge marked (black arrow), b. Representative graph showing PdG rise before the LH surge (blue arrow) and the gradual rise in PdG after LH peak (black arrow) for confirming ovulation as opposed to a single test mid-luteal phase (red arrow), c. Comparison of fold rise in PdG levels within 3 days after LH surge in ovulatory versus anovulatory cycles ( $* * * * p<0.0001$ and d. ROC analysis to evaluate the accuracy of the proposed criteria to predict ovulatory and anovulatory cycles.

\section{Discussion}


medRxiv preprint doi: https://doi.org/10.1101/2021.05.11.21257023; this version posted May 12, 2021. The copyright holder for this preprint (which was not certified by peer review) is the author/funder, who has granted medRxiv a license to display the preprint in perpetuity. All rights reserved. No reuse allowed without permission.

Optimal intercourse timing has been established as a key parameter influencing the frequency of pregnancy in women ${ }^{18}$. Previous studies have addressed the existence of a 6-day fertile window as the optimum fertile window correlated with an increased probability of pregnancy ${ }^{19,20}$. In addition, the fertile window prediction is well-correlated with the concentrations of urinary hormones, specifically the growth of E3G and LH. Nonetheless, about 37 percent of natural cycles are anovulatory $^{8}$ and may occur despite normal hormonal conduct for instance in case of luteinized unruptured follicles ${ }^{21,22}$. Thus, to ensure ovulation, the estimation of the fertile window is not adequate and therefore may not be well associated with pregnancy results as well.

The Inito Fertility Monitor (IFM) is a home-based diagnostic device which measures urinary E3G, PdG and LH concentrations. The Inito Fertility Monitor performance assessment was performed to calculate the accuracy and specificity of the Inito Fertility Monitor in the measurement of urine metabolites of interest. In predicting the values of E3G, PdG and LH in urine, IFM proved to be substantially close to laboratory based standard methods. In addition, the variability of the batch-to-batch was negligible and the interference was zero from other urine metabolites.

Since IFM is intended to be a home-based test, we offered IFM along with the test strips for women who were able to use the system at home for one menstrual cycle. We classified 40.2 percent of the menstrual cycles as anovulatory in the random trial we conducted, which is comparable but slightly higher than the 37 percent incidence recorded by previous studies. Moreover, the occasional cases of luteinized anovulation could also be captured, the frequency of which often coincides with what was previously recorded ${ }^{22}$. From the hormone data obtained, we propose a novel paradigm for faster confirmation of ovulation by virtue of continuous monitoring the urinary PdG. This paradigm could encompass all cycles that were classified as ovulatory according to the existing thresholds and methods of confirmation. In addition, it could also differentiate between ovulatory and anovulatory cycles in a statistically significant fashion indicating that this method of detecting ovulation is effective and accurate.

From the hormone trends, we also show that urinary PdG rises in a number of cycles before the LH surge. Previously, the occurrence a pre-ovulatory progesterone rise has been reported by Hoff et al. ${ }^{23}$ The role of this pre-ovulatory progesterone has been proposed to be triggering the LH surge and a premature rise in this has been indicated in the pathology of poly-cystic ovarian syndrome $(\mathrm{PCOS})^{24,25}$. The source of this progesterone has been hypothesized to be follicular and the surge is supposed to occur 12-24 hours before the expected LH surge. The progesterone surge observed by us happens much prior to this period and hence may be a separate phenomena possibly correlated to a particular developmental phase of the follicle. However, since the occurrence is highly conserved, it is likely that this feature may be an indicator of a common feature associated with normal natural cycles and could help in differentiating between other infertility related conditions.

\section{Conclusion}


medRxiv preprint doi: https://doi.org/10.1101/2021.05.11.21257023; this version posted May 12, 2021. The copyright holder for this preprint (which was not certified by peer review) is the author/funder, who has granted medRxiv a license to display the preprint in perpetuity. All rights reserved. No reuse allowed without permission.

The results from this study indicate that IFM is an accurate home-based fertility monitor to help women determine their fertile window as well as to confirm ovulation. IFM is sensitive enough to capture minute fluctuations in the urinary hormones and hence may also be used as an effective tool by clinicians in the continuous monitoring of hormones to identify novel trends. In the future, IFM may also serve as a platform to monitor the effects of interventions in case of infertility conditions and modify the interventions accordingly.

\section{References}

1 Zinaman M, Johnson S, Ellis J, Ledger W. Accuracy of perception of ovulation day in women trying to conceive. Curr Med Res Opin 2012. DOI:10.1185/03007995.2012.681638.

2 Kudesia R, Chernyak E, McAvey B. Low fertility awareness in United States reproductive-aged women and medical trainees: creation and validation of the Fertility \& Infertility Treatment Knowledge Score (FIT-KS). Fertil Steril 2017. DOI:10.1016/j.fertnstert.2017.07.1158.

3 Robinson JE, Wakelin M, Ellis JE. Increased pregnancy rate with use of the Clearblue Easy Fertility Monitor. Fertil Steril 2007.

4 Barrett JC, Marshall J. The risk of conception on different days of the menstrual cycle. Popul Stud (NY) 1969. DOI:10.1080/00324728.1969.10405297.

5 Wilcox AJ, Weinberg CR, Baird DD. Timing of Sexual Intercourse in Relation to Ovulation. Obstet Gynecol Surv 1996. DOI:10.1097/00006254-199606000-00016.

6 Royston P. Identifying the fertile phase of the human menstrual cycle. Stat Med 1991. DOI:10.1002/sim.4780100207.

7 Roos J, Johnson S, Weddell S, et al. Monitoring the menstrual cycle: Comparison of urinary and serum reproductive hormones referenced to true ovulation. Eur J Contracept Reprod Heal Care 2015. DOI:10.3109/13625187.2015.1048331.

8 Prior JC, Naess M, Langhammer A, Forsmo S. Ovulation prevalence in women with spontaneous normal-length menstrual cycles - A population-based cohort from HUNT3, Norway. PLoS One 2015. DOI:10.1371/journal.pone.0134473.

9 O'Connor KA, Brindle E, Miller RC, et al. Ovulation detection methods for urinary hormones: Precision, daily and intermittent sampling and a combined hierarchical method. Hum Reprod 2006. DOI:10.1093/humrep/dei497.

10 Santoro N, Crawford SL, Allsworth JE, et al. Assessing menstrual cycles with urinary hormone assays. Am J Physiol - Endocrinol Metab 2003. DOI:10.1152/ajpendo.00381.2002.

11 Thakur R, Akram F, Rastogi V, et al. Development of Smartphone-Based Lateral Flow Device for the Quantification of LH and E3G Hormones. IEEE Sens J 2020.

DOI:10.1109/jsen.2020.3008566. 
medRxiv preprint doi: https://doi.org/10.1101/2021.05.11.21257023; this version posted May 12, 2021. The copyright holder for this preprint

(which was not certified by peer review) is the author/funder, who has granted medRxiv a license to display the preprint in perpetuity. All rights reserved. No reuse allowed without permission.

12 O'Connor KA, Brindle E, Holman DJ, et al. Urinary estrone conjugate and pregnanediol 3-glucuronide enzyme immunoassays for population research. Clin Chem 2003. DOI:10.1373/49.7.1139.

13 Brindle E, Miller RC, Shofer JB, Klein NA, Soules MR, O’Connor KA. Urinary beta-luteinizing hormone and beta-follicle stimulating hormone immunoenzymometric assays for population research. Clin Biochem 2006. DOI:10.1016/j.clinbiochem.2006.08.009.

14 Park SJ, Goldsmith LT, Skurnick JH, Wojtczuk A, Weiss G. Characteristics of the urinary luteinizing hormone surge in young ovulatory women. Fertil Steril 2007. DOI:10.1016/j.fertnstert.2007.01.045.

15 Alliende ME. Mean versus individual hormonal profiles in the menstrual cycle. Fertil Steril 2002. DOI:10.1016/S0015-0282(02)03167-9.

16 Ecochard R, Leiva R, Bouchard T, et al. Use of urinary pregnanediol 3-glucuronide to confirm ovulation. Steroids 2013. DOI:10.1016/j.steroids.2013.06.006.

17 Leiva R, McNamara-Kilian M, Niezgoda H, Ecochard R, Bouchard T. Pilot observational prospective cohort study on the use of a novel home-based urinary pregnanediol 3-glucuronide (PDG) test to confirm ovulation when used as adjunct to fertility awareness methods (FAMs) stage 1. BMJ Open 2019. DOI:10.1136/bmjopen-2018-028496.

18 Stanford JB, White GL, Hatasaka H. Timing intercourse to achieve pregnancy: Current evidence. Obstet Gynecol 2002. DOI:10.1016/S0029-7844(02)02382-7.

19 Royston P, Ferreira A. A new approach to modeling daily probabilities of conception. Biometrics 1999. DOI:10.1111/j.0006-341X.1999.01005.x.

20 Dunson DB, Baird DD, Wilcox AJ, Weinberg CR. Day-specific probabilities of clinical pregnancy based on two studies with imperfect measures of ovulation. Hum Reprod 1999. DOI:10.1093/humrep/14.7.1835.

21 Killick S, Elstein M. Pharmacologic production of luteinized unruptured follicles by prostaglandin synthetase inhibitors. Fertil Steril 1987.

DOI:10.1016/S0015-0282(16)59163-8.

22 Qublan H, Amarin Z, Nawasreh M, et al. Luteinized unruptured follicle syndrome: Incidence and recurrence rate in infertile women with unexplained infertility undergoing intrauterine insemination. Hum Reprod 2006. DOI:10.1093/humrep/del113.

23 Hoff JD, Quigley ME, Yen SSC. Hormonal dynamics at midcycle: A reevaluation. J Clin Endocrinol Metab 1983. DOI:10.1210/jcem-57-4-792.

24 Dozortsev D, Pellicer A, Diamond MP. Progesterone is a physiological trigger of ovulatory gonadotropins. Fertil. Steril. 2020. DOI:10.1016/j.fertnstert.2019.12.024.

25 Dozortsev DI, Pellicer A, Diamond MP. Premature progesterone rise as a trigger of polycystic ovarian syndrome. Fertil. Steril. 2020. DOI:10.1016/j.fertnstert.2020.07.007. 
medRxiv preprint doi: https://doi.org/10.1101/2021.05.11.21257023; this version posted May 12, 2021. The copyright holder for this preprint (which was not certified by peer review) is the author/funder, who has granted medRxiv a license to display the preprint in perpetuity.

All rights reserved. No reuse allowed without permission.

\section{$\underline{\text { Tables }}$}

\begin{tabular}{|l|l|l|}
\hline & $\begin{array}{l}\text { Group I (samples } \\
\text { collected directly) } \\
(\mathrm{n}=100)\end{array}$ & $\begin{array}{l}\text { Group II (Using } \\
\text { IFM at home) } \\
(\mathrm{n}=52)\end{array}$ \\
\hline Age (y), mean (SD) & $27.3(4.6)$ & $27.6(4.1)$ \\
\hline Cycle length (d), mean (SD) & $30.4(6.3)$ & $27.6(5.4)$ \\
\hline BMI & & \\
\hline$<18.5, \mathrm{n}(\%)$ & $21(21)$ & $0(0)$ \\
\hline $18.5-24.9, \mathrm{n}(\%)$ & $66(66)$ & $41(78.9)$ \\
\hline $25-29.9, \mathrm{n}(\%)$ & $10(10)$ & $5(9.6)$ \\
\hline$>30, \mathrm{n}(\%)$ & $3(3)$ & $6(11.5)$ \\
\hline Trying to conceive, $\mathrm{n}(\%)$ & $31(31)$ & $52(100)$ \\
\hline
\end{tabular}

Table.1. Characteristics of eligible participants for the study 
medRxiv preprint doi: https://doi.org/10.1101/2021.05.11.21257023; this version posted May 12, 2021. The copyright holder for this preprint (which was not certified by peer review) is the author/funder, who has granted medRxiv a license to display the preprint in perpetuity.

a.

\begin{tabular}{|c|c|c|}
\hline & $\begin{array}{c}\text { Positive } \\
\text { (existing } \\
\text { criteria) }\end{array}$ & $\begin{array}{c}\text { Negative } \\
\text { (existing } \\
\text { criteria) }\end{array}$ \\
\hline $\begin{array}{c}\text { Positive } \\
\text { (proposed } \\
\text { criteria) }\end{array}$ & 55 & 0 \\
\hline $\begin{array}{c}\text { Negative } \\
\text { proposed } \\
\text { criteria) }\end{array}$ & 0 & 45 \\
\hline
\end{tabular}

b.

\begin{tabular}{|c|c|c|}
\hline & $\begin{array}{c}\text { Positive } \\
\text { (existing } \\
\text { criteria) }\end{array}$ & $\begin{array}{c}\text { Negative } \\
\text { (existing } \\
\text { criteria) }\end{array}$ \\
\hline $\begin{array}{c}\text { Positive } \\
\text { (proposed } \\
\text { criteria) }\end{array}$ & 18 & 0 \\
\hline $\begin{array}{c}\text { Negative } \\
\text { proposed } \\
\text { criteria) }\end{array}$ & 0 & 4 \\
\hline
\end{tabular}

Table.2. Decision matrices comparing the outcomes of prediction of ovulation between the existing criteria (mid-luteal phase measurement) and proposed criteria (criteria III proposed using IFM) applied to Group I (a) and Group II (b). Positive and negative indicate ovulatory and anovulatory respectively. 
medRxiv preprint doi: https://doi.org/10.1101/2021.05.11.21257023; this version posted May 12, 2021. The copyright holder for this preprint (which was not certified by peer review) is the author/funder, who has granted medRxiv a license to display the preprint in perpetuity.

\section{Supplementary Data}

Supplementary Table.1. List of chemical standards from Sigma-Aldrich used in the evaluation of IFM along with the catalog numbers

\begin{tabular}{|c|c|}
\hline Chemical standard & Lot Number \\
\hline LH & L6420 \\
\hline $\mathrm{HCG}$ & 230734 \\
\hline Progesterone & P0130 \\
\hline Pregnanediol & 903620 \\
\hline Estone-3-Glucuronide & E2127 \\
\hline Acetaminophen & A3035 \\
\hline Ascorbic Acid & A7506 \\
\hline Caffeine & $\mathrm{C} 0750$ \\
\hline Glucose & Y0001745 \\
\hline Ampicillin & A9518 \\
\hline Ketone & 179124 \\
\hline Acetylsalicylic Acid & A3160 \\
\hline Hemoglobin & ERMAD500 \\
\hline Tetracycline & 31741 \\
\hline Nitrite Positive & 1.06549 \\
\hline Phenothiazine & 46624 \\
\hline Ethanol & 02870 \\
\hline Albumin & A2153 \\
\hline
\end{tabular}

Supplementary Table.2. Dilution protocol for preparing samples of E3G, PdG and LH in spiked male urine

Stock concentration E3G: 1000ng/mL

Stock concentration LH: $1000 \mathrm{mIU} / \mathrm{mL}$

Stock concentration PdG: 50ug/mL 
medRxiv preprint doi: https://doi.org/10.1101/2021.05.11.21257023; this version posted May 12, 2021. The copyright holder for this preprint (which was not certified by peer review) is the author/funder, who has granted medRxiv a license to display the preprint in perpetuity.

\begin{tabular}{|l|l|l|l|l|l|l|l|}
\hline $\mathbf{N r}$ & $\begin{array}{l}\text { Target conc. } \\
\text { E3G }(\mathbf{n g} / \mathbf{m L})\end{array}$ & $\begin{array}{l}\text { Target } \\
\text { conc. } \mathbf{L H} \\
{[\mathbf{m I U} / \mathbf{m l}]}\end{array}$ & $\begin{array}{l}\text { Target } \\
\text { conc. } \\
\mathbf{P d G}[\boldsymbol{\mu g} / \mathbf{m l}]\end{array}$ & $\begin{array}{l}\text { E3G } \\
(\boldsymbol{\mu l})\end{array}$ & $\begin{array}{l}\mathbf{L H} \\
(\boldsymbol{\mu l})\end{array}$ & $\begin{array}{l}\text { PdG } \\
(\boldsymbol{\mu l})\end{array}$ & $\begin{array}{l}\text { Spiked } \\
\mathbf{u r i n e} \\
(\boldsymbol{\mu l})\end{array}$ \\
\hline $\mathbf{1}$ & 0 & 0 & 0 & 0 & 0 & 0 & 2000 \\
\hline $\mathbf{2}$ & 10 & 2 & 3 & 20 & 4 & 120 & 1756 \\
\hline $\mathbf{3}$ & 20 & 4 & 6 & 40 & 8 & 240 & 1712 \\
\hline $\mathbf{4}$ & 35 & 10 & 9 & 70 & 20 & 360 & 1550 \\
\hline $\mathbf{5}$ & 50 & 20 & 12 & 100 & 40 & 480 & 1380 \\
\hline $\mathbf{6}$ & 75 & 40 & 15 & 150 & 80 & 600 & 1170 \\
\hline
\end{tabular}

Supplementary Table.3. Inter-lot precision analysis of Inito fertility test strips at four concentrations of E3G:10, 35, 50 and 100ng/mL, PdG: 3, 6, 12 and 15ug/mL and LH: 2, 8, 10 and $40 \mathrm{mIU} / \mathrm{mL}$

\begin{tabular}{|c|c|c|c|c|c|c|c|c|}
\hline $\begin{array}{l}\text { Pd } \\
\text { G } \\
\text { con } \\
\text { c }\end{array}$ & $\begin{array}{l}\text { Re-predict } \\
\text { ed PdG } \\
\text { conc }\end{array}$ & $\begin{array}{l}\text { PdG } \\
\text { CV }\end{array}$ & $\begin{array}{l}\text { Spiked } \\
\text { E3G } \\
\text { conc }\end{array}$ & $\begin{array}{ll}\text { Re-predict } \\
\text { ed E3G } \\
\text { conc }\end{array}$ & $\begin{array}{l}\text { E3 } \\
\text { G } \\
\text { CV }\end{array}$ & $\begin{array}{l}\text { Spiked } \\
\text { LH } \\
\text { conc }\end{array}$ & $\begin{array}{l}\text { Re-predicted } \\
\text { LH conc }\end{array}$ & $\begin{array}{l}\mathrm{LH} \\
\mathrm{CV}\end{array}$ \\
\hline \multirow[t]{10}{*}{3} & 3.09 & $\begin{array}{l}6.6 \\
\%\end{array}$ & 10 & 8.2 & $\begin{array}{l}7.2 \\
\%\end{array}$ & 2 & 1.95 & $\begin{array}{l}9.1 \\
\%\end{array}$ \\
\hline & 2.87 & & & 9.61 & & & 1.98 & \\
\hline & 3.43 & & & 9.8 & & & 2.14 & \\
\hline & 2.89 & & & 10.57 & & & 2.28 & \\
\hline & 2.91 & & & 9.3 & & & 2.56 & \\
\hline & 3.28 & & & 8.69 & & & 2.3 & \\
\hline & 3.37 & & & 8.83 & & & 2.27 & \\
\hline & 3.19 & & & 9.58 & & & 1.98 & \\
\hline & 2.95 & & & 9.95 & & & 1.93 & \\
\hline & 3.08 & & & 9.38 & & & 2.04 & \\
\hline 6 & 5.15 & $\begin{array}{l}5.8 \\
\%\end{array}$ & 35 & 34.57 & $\begin{array}{l}4.8 \\
\%\end{array}$ & 8 & 7.68 & $\begin{array}{l}3.1 \\
\%\end{array}$ \\
\hline & 5.48 & & & 31.19 & & & 7.84 & \\
\hline
\end{tabular}


medRxiv preprint doi: https://doi.org/10.1101/2021.05.11.21257023; this version posted May 12,2021 . The copyright holder for this preprint (which was not certified by peer review) is the author/funder, who has granted medRxiv a license to display the preprint in perpetuity. All rights reserved. No reuse allowed without permission.

\begin{tabular}{|c|c|c|c|c|c|c|c|c|}
\hline & 5.57 & & & 33.6 & & & 8.03 & \\
\hline & 6.03 & & & 36.48 & & & 8.15 & \\
\hline & 6.19 & & & 35.07 & & & 8.52 & \\
\hline & 5.92 & & & 32.5 & & & 7.91 & \\
\hline & 6.08 & & & 33.09 & & & 7.99 & \\
\hline & 5.87 & & & 34.52 & & & 8.18 & \\
\hline & 6.19 & & & 35.8 & & & 8.20 & \\
\hline & 5.88 & & & 35.47 & & & 8.38 & \\
\hline 12 & 11.88 & $\begin{array}{l}4.4 \\
\%\end{array}$ & 50 & 51.53 & $\begin{array}{l}3.6 \\
\%\end{array}$ & 10 & 10.48 & $\begin{array}{l}6.5 \\
\%\end{array}$ \\
\hline & 13.01 & & & 46.39 & & & 10.59 & \\
\hline & 11.88 & & & 49.82 & & & 9.44 & \\
\hline & 12.09 & & & 51.09 & & & 9.52 & \\
\hline & 12.58 & & & 48.74 & & & 9.89 & \\
\hline & 12.62 & & & 50.29 & & & 9.01 & \\
\hline & 13.2 & & & 51.19 & & & 10.92 & \\
\hline & 11.79 & & & 47.65 & & & 10.63 & \\
\hline & 11.85 & & & 50.39 & & & 10.84 & \\
\hline & 11.82 & & & 51.86 & & & 10.27 & \\
\hline 15 & 14.03 & $\begin{array}{l}3.7 \\
\%\end{array}$ & 100 & 110.24 & $\begin{array}{l}4.2 \\
\%\end{array}$ & 40 & 37.11 & $\begin{array}{l}3.6 \\
\%\end{array}$ \\
\hline & 14.58 & & & 103.42 & & & 41.37 & \\
\hline & 15.08 & & & 100.37 & & & 39.6 & \\
\hline & 15.88 & & & 98.65 & & & 40.58 & \\
\hline & 15.83 & & & 99.07 & & & 39.67 & \\
\hline & 14.68 & & & 105.48 & & & 41.37 & \\
\hline & 14.9 & & & 102.49 & & & 42.38 & \\
\hline
\end{tabular}


medRxiv preprint doi: https://doi.org/10.1101/2021.05.11.21257023; this version posted May 12, 2021. The copyright holder for this preprint (which was not certified by peer review) is the author/funder, who has granted medRxiv a license to display the preprint in perpetuity.

\begin{tabular}{|l|l|l|l|l|l|l|l|l|}
\hline & 15.08 & & & 99.61 & & & 40.19 & \\
\hline & 15.25 & & & 100.03 & & & 40.19 & \\
\hline & 15.25 & & & 109.86 & & & 41.28 & \\
\hline
\end{tabular}

Supplementary Table 4. Cross reactivity analysis of Inito Fertility test strips with different urine metabolites

\begin{tabular}{|l|l|l|l|l|}
\hline $\begin{array}{l}\text { Interfering } \\
\text { substance }\end{array}$ & $\begin{array}{l}\text { Concentrati } \\
\text { on }\end{array}$ & $\begin{array}{l}\text { PdG } \\
\text { test }\end{array}$ & $\begin{array}{l}\text { E3G } \\
\text { test }\end{array}$ & $\begin{array}{l}\text { LH } \\
\text { test }\end{array}$ \\
\hline LH & $600 \mathrm{mIU} / \mathrm{mL}$ & No & No & NA \\
\hline hCG & $\begin{array}{l}10000 \mathrm{mIU} / \\
\mathrm{mL}\end{array}$ & No & No & No \\
\hline Progesterone & $100 \mathrm{ng} / \mathrm{mL}$ & No & No & No \\
\hline Pregnanediol & $60 \mathrm{ug} / \mathrm{mL}$ & NA & No & No \\
\hline $\begin{array}{l}\text { Estrone-3-glucuro } \\
\text { nide }\end{array}$ & $600 \mathrm{ng} / \mathrm{mL}$ & No & NA & No \\
\hline Ethanol & $1 \%$ & No & No & No \\
\hline Albumin & $100 \mathrm{mg} / \mathrm{dL}$ & No & No & No \\
\hline Glucose & $2000 \mathrm{mg} / \mathrm{dL}$ & No & No & No \\
\hline Ketone & $1 \%$ & No & No & No \\
\hline Ampicillin & $20 \mathrm{mg} / \mathrm{dL}$ & No & No & No \\
\hline
\end{tabular}

